\title{
Mobility Behavior Analysis of Migrant from Java in South Kuta-Bali
}

\author{
I Made Sarmita ${ }^{1}$, Ida Bagus Made Astawa ${ }^{2}$ \\ \{made.sarmita@undiksha.ac.id ${ }^{1}$,bagus.astawa@undiksha.ac.id² \\ Universitas Pendidikan Ganesha, Indonesia ${ }^{12}$
}

\begin{abstract}
The purpose of this study was to determine the mobility behavior indicated by the mobility intensity of migrants from Java as well as to prove its relationship with the variables of distance, length of stay, economic conditions, and migrant marital status. To achieve this objective, this study used a survey design with the research subjects being migrants from Java in South Kuta who were taken using snowball sampling techniques. Data analysis was carried out separately, each using quantitative descriptive techniques, product moment correlation, and biserial point correlation by considering the scale of the research data used. The results obtained were the mobility behavior indicated by the intensity of the mobility was very varied and categorized as very strong, the lowest was once a year and the highest reached ten times as far as he knew. Mobility intensity is negatively related $(-0.259)$ and significant at the $1 \%$ level $(0.009<0.01)$ with the distance variable, negatively related $(-0.268)$ and significant at the $1 \%$ level $(0.007<0.01)$ with the length of stay variable, positive correlation (0.508) and significant at the level of $1 \%$ $(0.000<0.01)$ with variable economic conditions, and does not have a significant relationship with the marital status variable of migrants with a correlation value of -0.156 (conversion to a $t$ value of -1.560 is more small from the $t$ table value of 1.987) and a significance value of 0.122 This finding contributed to the development of mobility theories and has implications for input in the formulation of population policy planning.
\end{abstract}

Keywords: Mobility Intensity; Distance; Length of Stay; Economic Conditions; Marital Status

\section{Introduction}

Assessment of population mobility both regionally and at the micro level is very important. This is because on the one hand there is an uneven population density and distribution, the push and pull factors for people to do mobility, the problems that arise both in the area of origin [1], in the destination area, the existence of decentralization and autonomy regions, and on the other hand, there is communication [2], including transportation, which is getting smoother.

Recently there has been a flow of population movement (migration) from Java to outside Java, one of which is to the island of Bali, where the population density condition is not much different from the conditions in Java. This migration flow is caused by the 
availability of transportation facilities and infrastructure, both land, sea and air, which connects the two regions in addition to the relatively close distance between the two regions when compared to other regions. There are also other factors that support the flow of migration, namely the promotion of developments in all fields for the provinces outside Java, such as education, trade and industry. This is able to attract migrants to go to the area which in turn has consequences for the destination area.

The appointment of Bali as the center for tourism development in the central part of Indonesia had an impact on its rapid economic growth. On the other hand, it is automatically always preoccupied with population problems, especially those caused by the relatively high population growth as a contribution to positive net migration. Bali's population growth in 2010-2015 was $1.23 \%$, slightly lower than the national population growth in the same period of $1.38 \%$. However, when broken down by district, the highest population growth in the same period occurred in Badung Regency at $2.43 \%$, far exceeding the national and Bali population growth (BPS, 2016). It is even more imbalanced when the population growth rate in Badung Regency is seen by sub-district, which shows that South Kuta District has an overloaded population growth rate $(5 \%)$ (Exponential calculations from the data from South Kuta in Figures 2011 and 2019) [3];[4].

Population growth in South Kuta far exceeds the minimum limit ( $>2.5 \%$ per year), reflecting that population movement (in-migration) greatly contributes to this population growth rate. That said, because the trend of the number of in-migration has always been greater than that of outgoing migration in the last few periods. Population problems, especially the migrant population in the South Kuta area, are now becoming increasingly prominent. Like the proverb "there is sugar there is ants", the sparkling world of tourism not only attracts tourists to visit, but also stimulates the presence of migrants to earn a fortune in this area. Of the existing migrants, it is believed that there are migrants from Java. It is said that because from the results of initial observations it is very easy to find migrants from Java in every corner of the region in South Kuta, both those working in the formal sector and especially in the informal sector. In addition, it is realized that the migration process of migrants from Java to Bali in general and South Kuta in particular has long historical roots and this process has developed due to the distance between the two regions which are close and the smooth transportation connection. With the arrival of these migrants, the condition of the population in South Kuta is getting more heterogeneous which can be a trigger for the emergence of social problems. If the issue of migrants is not clearly identified, it is feared that it will cause more complex problems and can affect the image of Bali as a whole.

One of the basic steps that can be taken in order to identify these migrants is to study their mobility behavior. Mobility behavior can be shown from the intensity of mobility carried out by migrants to return to their home areas within a certain period of time. This mobility behavior certainly does not stand as a single variable, but has a relationship and can even be predicted using several other variables. Similar research results have been conducted by Sarmita (2017 and 2018) with research subjects with educational motive backgrounds. The results show that the mobility behavior of migrants is influenced by the distance between the origin and the destination areas, but not by the length of stay in the destination area, economic conditions, and their attachment to the origin [5];[6]. Reflecting on this, this research is 
interesting to do by applying it to subjects with different migration backgrounds by trying to connect their mobility behavior with a variety of more complex variables including variables of distance, length of stay, economic conditions, and the marital status of migrants. Apart from being interesting in the framework of developing a study of population mobility material, it is also important to do this given the increasingly diverse characteristics of the population in South Kuta. Therefore, the purpose of this study was to determine the mobility behavior indicated by the mobility intensity of migrants from Java as well as to prove its relationship with the variables of distance, length of stay, economic conditions, and migrant marital status.

\section{Method}

The research design used in this study was a survey, namely a method of collecting information from a number of samples as respondents facilitated by a questionnaire. Sampling of the area / location was determined by purposive sampling and individual sampling was determined by the snowball sampling technique. The number of respondents involved through the snowball technique was 100 people.

Data Analysis used to achieve the research objectives is descriptive techniques, namely providing descriptive explanations / analyzes of the quantitative data obtained related to the intensity of mobility carried out by migrants from Java in South Kuta. In addition, data analysis was also carried out using correlation techniques that are parametric and nonparametric. To see the relationship between the variable distance, length of stay, and economic conditions with the intensity of mobility, the product moment correlation technique is used, and to see the relationship between marital status and the intensity of mobility using the point biserial correlation technique.

\section{Result and Discussions}

\section{The intensity of mobility by migrants from Java in South Kuta}

The mobility intensity implies that in the past year, how many times did the respondent (migrant) return to their home area in Java. From the data obtained, at least migrants have returned to Java at least once in the last 1 year. If migrants return home after one period of staying in another place, the intensity is very strong, if they move again before returning home, they are still included in circular migration but it is a process that is less important. Of the 100 migrants from Java who were respondents, the intensity of their mobility in the past year is varied, which can be seen in Figure 1.

The migrants from Java in South Kuta who had returned to their home areas in Java in the past year were at most 1 time, reaching 38\%. A fairly large percentage is also shown in the intensity of returning to their place of origin in the past year is 2 times, 4 times and 3 times, which reached $32 \%, 12 \%$ and $9 \%$ respectively. The more often they return to their home areas in Java, the higher the intensity of their mobility. Distance and affordable costs and easy transportation facilities make the intensity of returning to the area of origin high. On average, respondents stated that they returned to their hometowns in Java because of the 
reasons for the Eid homecoming, family reasons, or business / work interests that support their work overseas. The reasons for returning migrants to their hometowns are quite heterogeneous, as is the case with Garcia's research [7].

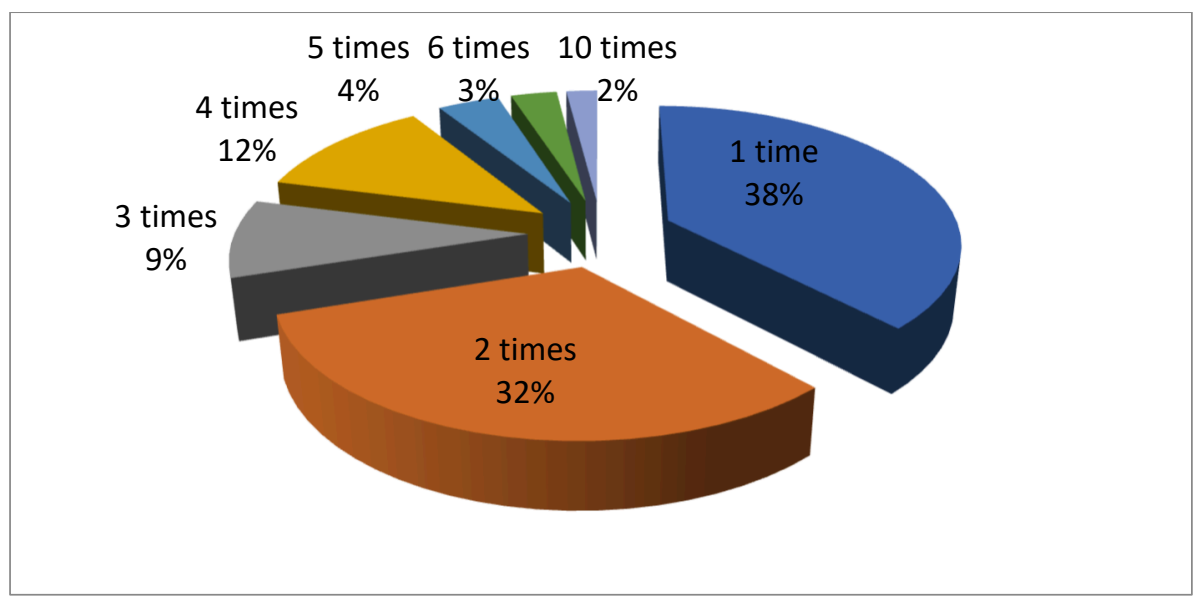

Figure 1 The Mobility Intensity of Migrants from Java in the Last 1 Year

The varying intensity of mobility of migrants cannot be explained by this single variable, but it needs further analysis by relating it to the various factors (variables) that can influence it. This will be explained in the next discussion. The intensity of mobility carried out by migrants from Java further strengthens the findings of previous studies related to the Migration typology of migrant from Java by Sarmita, I. M., \& Simamora, A. H. (2018). In the study, it was revealed that the migration typology of migrants from Java was mostly circular potential migrants, that is, they intend not to stay in South Kuta and have currently lived in the migration area for less than 5 years. With no intention of staying and only staying for a while in overseas areas, the intensity of his mobility is high. Those who intend not to stay and have only been living overseas for a while are always imagined by their home area [8]. Norris argues that the factor of origin is an important factor. In the area from which a person is born, and before school that person lives in that area. He knows very well about the environmental conditions of his hometown, is full of "nostalgia" when he lives and lives in his hometown and plays with his peers. That is why one is so attached to one's place of origin. Similar to Beyaz research (2020), in the end migrants will return to their place of origin with varying intensities to meet the need for personal loyalties and nostalgia, and sometimes for keeping the motivation of passing it down to next generation alive [9]. With such a high attachment to the area of origin, the intensity of the mobility that is carried out becomes even stronger.

The Relationship between Distances, Length of Stay, Economic Conditions, and Marital Status of Migrants with the Intensity of Mobility

The intensity of mobility, which indicates the level of frequency of doing mobility to return to the area of origin, is not sufficiently explained by a single variable, but it needs further analysis regarding the variables that are thought to have a relationship with it. In theory, there are several variables that can explain further the intensity of the mobility undertaken, namely the distance between the origin and destination areas, the length of stay in the migration destination, the economic conditions of the migrants, and the marital status of 
the migrants themselves. Based on the research results, the relationship between the variables mentioned with the intensity of mobility can be seen in the following table 1 .

\begin{tabular}{lccccc}
\hline \multicolumn{7}{c}{ Table 1. Correlation Between Variables } \\
& $\begin{array}{c}\text { Intensity } \\
\text { Of } \\
\text { Mobility }\end{array}$ & Distance & $\begin{array}{c}\text { Long of } \\
\text { Stay }\end{array}$ & $\begin{array}{c}\text { Economi } \\
\text { c } \\
\text { Conditio } \\
n\end{array}$ & Marital \\
& & & & Status \\
\hline Pearson Correlation & 1 & $-.259^{* *}$ & $-.268^{* *}$ & $.508^{* *}$ & -.156 \\
\hline Sig. (2-tailed) & 100 & .009 & .007 & .000 & .122 \\
\hline $\mathrm{N}$ & 100 & 100 & 100 & 100 \\
\hline Source: Primary & & & & &
\end{tabular}

Source: Primary Data Processing

Information of column 6 (Marital Status): $r$ table value $=-0,156$, converted to $t$ table value $=-1,560$

The results of statistical tests are presented in table 1, showing that the relationship between mobility intensity and the distance from the origin to destination is negative $(-0.259)$ and significant at the $1 \%$ level $(0.009<0.01)$. From this value, it will further strengthen the existing theory. The closer the distance to the area of origin, the higher the intensity of the mobility taken to return to the area, and vice versa. The relatively close distance between the area of origin and South Kuta as the destination for migration makes it easier for migrants to return to their home areas because it is related to the transportation costs that must be incurred. With a short distance, transportation costs will be cheaper and more affordable. This is in line with the results of research conducted by Sarmita and Treman (2017) with migrants with different motives (education). In the study, it was stated that migrants who in this case are students, the intensity of mobility carried out to return to their respective areas of origin is getting lower as the distance from their home areas is getting further [5]. The results of this study are also in line with the research of Walii, Fiqih, and Sukamdi (2012), which found that there was a change in the mobility pattern of the population of Bangkalan Regency to Surabaya City from permanent to non-permanent after the Suramadu Bridge. With this bridge, it makes the distance and accessibility to the destination easier so that the costs incurred will be more affordable. Thus the intensity of the mobility that is carried out will be higher so that it changes the pattern of mobility that is carried out [10]. Overall, the results of this study are very much in line with what Reivenstein said [11] and Wang et all [12], where the distance factor is the main determinant and conditional of people migrating.

The relationship between length of stay and mobility intensity based on the table above is negative $(-0.268)$ and significant at the $1 \%$ level $(0.007<0.01)$. From this value, it will further strengthen the existing theory. The longer a migrant stays in the destination area, the lower the intensity of the mobility taken to return to the area, and vice versa. Migrants who have worked in the destination area for a long time have been able to forge new kinship relationships with the community / environment in the destination area and intend to stay so that the intensity of returning to the area of origin is low. The longer the migrant has lived in the destination area, the smaller the probability of carrying out circular migration, in other words the migrant will eventually choose to staying, the intensity of returning to the area of origin becomes smaller. In contrast to those who are new or have recently resided in the destination area, it is difficult to adapt to the new environment so that from them a desire to continue to return to their original area has increased the intensity of their mobility. In general, recent migrants when they first set foot in their destination, fond memories of their families 
and relatives in their hometowns still remain in the memory of each of the mobility actors. In addition, they don't have many friends yet, are still unfamiliar with the new territory and in the end they can be said to be new in the process of adjusting to themselves [13]. In many cases, such as the results of research by Gherghina (2020), show that migrants often receive discrimination treatment by indigenous people, making migrants, especially recent migrants, always want to return to their home areas [14]. First jobs were often characterized by precarity and poor working conditions. Most recent migrant had little knowledge about their rights at work and were not sure what to do when mistreated or were asked to do something unsafe at work [15]. This makes them always want to return to their home area so that the intensity of their mobility becomes high. The results of this study are different from the results of research by Sarmita and Treman (2017) which examined the relationship between length of stay and the mobility intensity of mobility actors with educational motives. In this study, there was no relationship between the length of stay and the intensity of the mobility undertaken, in the sense that both old and recent migrants living at the destination, the intensity of mobility to return to their respective places of origin was the same, did not show any differences which means [5]. With these results, it can be said that the intensity of mobility will vary and the variable of length of stay will determine which depends on the motives or background of the migrants themselves. Migrants with educational motives stated that there was no relationship, while migrants with economic motives (migrants in this study) found a negative relationship between length of stay and intensity of mobility, in accordance with existing theories.

The economic condition of migrants has a positive $(0.508)$ and significant relationship at the $1 \%$ level $(0.000<0.01)$ with the intensity of mobility. The higher / better the economic condition of the migrants (as indicated by the income they earn), the higher the intensity of mobility to return to their home areas. The high income earned makes it easier for them to access everything, including the convenience for them to return to their respective areas of origin. The cost factor is not an obstacle for this group as a burden on transportation expenses to return to their home areas. On the other hand, for migrants who are in a less favorable financial condition, the transportation cost factor is certainly a separate calculation. The more often they return to their home areas, the higher the costs. For this reason, this group prefers to return to their home areas at certain moments such as the Eid homecoming which occurs once a year, so that transportation costs can be minimized. The results of this study are similar to the findings of Rustariyuni (2013), namely the economic variables, in this case is the wages received, have a positive and significant effect on the decision to make non-permanent migration to Denpasar City[16]. However, the results of this study are different from research by Sarmita (2018) which looks at the effect of economic conditions on the intensity of mobility carried out by migrants with educational backgrounds. In this study, the effect of economic conditions was not found on the intensity of mobility undertaken, in the sense that for both established and non-established migrants, the intensity of the mobility undertaken to return to their home regions was not different [6]. It can be understood that migrants with educational backgrounds are still very dependent on their parents, do not or do not have thoughts as far as migrants with economic backgrounds in applying economic principles like migrants from Java in South Kuta.

For the last variable (married status), the correlation value needs to be converted into at value because the analysis used is different from the previous variable. The conversion result of the $r$ value of -0.156 to the $t$ value is -1.560 . The provisions used are if the value of $t$ count $>\mathrm{t}$ table, then there is a significant relationship. The $\mathrm{t}$ table value (referring to the statistics book attachment) is 1.987 . The value of $t$ count $<t$ table $(-1,560<1,987)$. This is reinforced by the significance value in table 1 which shows the number 0.122 , which is not 
significant at the $5 \%$ level and let alone $1 \%$. With the results of these calculations, there is no significant relationship between mobility intensity and marital status. Both those who are married and others (single, widowed, widower) do not show significant differences in the intensity of mobility. On the one hand, there are those who are married who have a high intensity of mobility, not a few who have low mobility. Likewise what happened to migrants from Java with other statuses, the intensity of their mobility varied. However, from data processing carried out descriptively, it can be seen that the average mobility intensity of currently married migrants is 2.1 times per year, while the mobility intensity of migrants with other statuses (single, widowed, widower) is 2.7 times. Descriptively what Reveinstein said is little proven [11], but not statistically the case. The results of this study are different from the findings of Yasa and Agustina (2013), who found that the marital status of migrants in Denpasar City greatly determines them to stay or the intensity of mobility to return to their home areas is low [17]. Otherwise the findings from Ham (2007) who found that separation leads to an increase in mobility [18]. The intensity of mobility that occurs also seems to be determined by the presence of the family in the migration destination.

\section{Conclusion}

The mobility intensity to return to their place of origin by migrants from Java is varies, the lowest is once a year and the highest is 10 times a year. Overall, the intensity of mobility carried out by all categorized migrants is very strong. Mobility intensity is related to several variables. These variables are the distance between the origin-destination area which has a negative relationship $(-0.259)$ and is significant at the $1 \%$ level $(0.009<0.01)$, the length of stay which has a negative relationship (-0.268) and significant at the $1 \%$ level $(0.007$ $<0.01$ ), and economic conditions that have a positive relationship (0.508) and significant at the $1 \%$ level $(0.000<0.01)$. Meanwhile, the married status variable does not have a significant relationship with the intensity of mobility with a correlation value of $-0.156(t=-1.560$, which is smaller than $t$ table of 1.987) and a significance value of $0.122>0.05$. This finding will have implications for the development of mobility theories, where a theory does not apply absolutely if it is applied to the conditions of areas and populations that have different characteristics. In addition, these findings also contribute to the practical realm for the government as input in formulating population policies, especially in relation to migrants whose existence is increasingly complex in South Kuta.

\section{References}

[1] F. M. Critelli, L. A. Lewis, A. C. Yalim, and J. Ibraeva, "Labor Migration and Its Impact on Families in Kyrgyzstan: a Qualitative Study," J. Int. Migr. Integr., 2020, doi: 10.1007/s12134-020-00781-2.

[2] R. Serbeh and P. O.-W. Adjei, "Social Networks and the Geographies of Young People's Migration: Evidence from Independent Child Migration in Ghana," J. Int. Migr. Integr., vol. 21, no. 1, pp. 221-240, 2020, doi: https://doi.org/10.1007/s12134019-00720-w.

[3] Badan Pusat Statistik, "Kuta Selatan in Figure (in Bahasa)," Badung, 2011.

[4] Badan Pusat Statistik, "Kuta Selatan in Figure (in Bahasa)," Badung, 2019. 
[5] I. M. Sarmita and I. W. Treman, "Study of Population Mobility: Micro Analysis of Student Mobility Behavior of Geography Education Department, Ganesha University of Education (in Bahasa)," J. Ilm. Ilmu Sos., vol. 3, no. 2, pp. 117-128, 2017, doi: http://dx.doi.org/10.23887/jiis.v3i2.16519.

[6] I. M. Sarmita, The Influence of Economic Conditions and Activities in the Region of Origin on the Mobility Intensity of Undiksha Geography Education Department Students (in Bahasa). LPPM Undiksha, 2018.

[7] T. García-Pereiro, "Clustering Reasons for Returning: an Overview of Return Migration in Albania," J. Int. Migr. Integr., vol. 20, no. 2, pp. 361-374, 2019, doi: https://doi.org/10.1007/s12134-018-0611-z.

[8] I. M. Sarmita and A. H. Simamora, "Socio-Economic Characteristics and Migration Typology of Migrant from Java in South Kuta-Bali (in Bahasa)," J. Ilm. Ilmu Sos., vol. 4, no. 2, pp. 132-143, 2018, doi: http://dx.doi.org/10.23887/jiis.v4i2.16528.

[9] C. Beyaz, "Lives Without a Last Stop Rural Migrant, Return Migration, and Practice of Multiple Place," Insan \& Toplum, vol. 10, no. 1, pp. 145-175, 2020, doi: https://doi.org/10.12658/M0329.

[10] W. Al, F. Nuruddin, and Sukamdi, "Changes in Population Mobility Patterns from Bangkalan Regency to Surabaya City (Case of Labang District, Bangkalan Regency) (in Bahasa)," J. Bumi Indones., vol. 1, no. 3, 2012.

[11] M. J. Greenwood, "The migration legacy of E. G. Ravenstein,” Migr. Stud., vol. 7, no. 2, pp. 269-278, 2019, doi: https://doi.org/10.1093/migration/mny043.

[12] X. Wang, S. Ding, W. Cao, D. Fan, and B. Tang, "Research on Network Patterns and Influencing Factors of Population Flow and Migration in the Yangtze River Delta Urban Agglomeration, China," Sustainability, vol. 12, no. 6803, p. 6803, 2020, doi: https://doi.org/10.3390/su12176803.

[13] I. M. Sarmita, S. R. Giyarsih, and Umi Listyaningsih, "Migration Intentions of Circular Migrants from Java to South Kuta District-Bali," Rom. Rev. Reg. Stud., vol. IX, no. 3, pp. 37-46, 2013.

[14] S. Gherghina, "Work and Stay: Explaining Perceived Discrimination Among Romanian Labor Migrants," Int. Migr. Integr., 2020, doi: https://doi.org/10.1007/s12134-020-00777-y.

[15] A. Kosny, B. Yanar, M. Begum, and E. Al, "Safe Employment Integration of Recent Immigrants and Refugees," Int. Migr. Integr., pp. 807-827, 2020, doi: https://doi.org/10.1007/s12134-019-00685-w.

[16] S. D. Rustariyuni, "Factors affecting the Interest of Migrants to Perform NonPermanent Mobility to the City of Denpasar (in Bahasa)," J. Ekon. dan Bisnis, vol. 2, pp. 95-104, 2013.

[17] I. G. W. M. Yasa and P. W. Agustina, "The Influence of Socio-Demographic and Economic Factors on Decisions of Wanting or Not to Stay as Mobility Actors in Denpasar City (in Bahasa)," J. Ekon. Pembang. Univ. Udayana, vol. 2, no. 10, 2013.

[18] M. van Ham and P. Feijten, "Residential mobility and migration of the separated," Demogr. Res., vol. 17, p. 21, 2007, [Online]. Available: http://www.demographicresearch.org/. 